\title{
The Effectiveness of Online Learning on Bahasa Indonesia During Covid-19 Pandemic
}

\begin{abstract}
Andi Fathul Asdar
Makassar, Indonesia

Email: andi.fathul.asdar@gmail.com

ABSTRACT

Online learning has become normal during covid-19 pandemic. This study aims to determine the effectiveness of online learning on Bahasa Indonesia during the covid-19 pandemic. This research used a mixed method research and data were collected using test, questionnaires, and interviews to obtain complete information related to the effectiveness of online learning. Bahasa Indonesia is measured in four aspects consisting of listening, speaking, reading and writing. The results showed that online learning can be effective in listening and reading aspects but ineffective in speaking and writing aspects.
\end{abstract}

Keywords: Online learning, bahasa Indonesia, covid-19 pandemic

\section{INTRODUCTION}

Covid-19 is a disease that can spread, either directly or indirectly, from one person to another. This condition attacks the respiratory system such as the nose, throat and lungs. The complexity of handling the outbreak, the absence of vaccines and drugs to cure Covid patients has made the government implement strict policies to break the chain of the spread of Covid-19. One way to break the chain of spreading Covid-19 is by limiting community interaction which is applied by means of physical distancing. However, this physical distancing policy can inhibit the rate of growth in various fields of life, both in the economic, social, and of course education fields. The government took a policy for the implementation of distance learning, not through classroom as usual.

The existence of a distance learning policy during the pandemic has encouraged teachers to carry out online learning. Learning is done by using cellphones in providing subject matter and assignments to students. Students study at their respective homes by receiving material that the teacher has distributed online. Learning that is carried out using an online system makes subject matter more easily and broadly accessible to students. This makes it easier for teachers and students to continue teaching and learning even though they are doing physical distancing in accordance with recommendations from the government.

Online learning is learning that is carried out using digital tools or content. It was first recognized for the influence of the development of electronic-based learning (e-learning). Urdan and Weggen (as cited in Keengwe \& Georgina, 2012) said online learning is a subset of distance education and embraces a wide set of technology applications and learning processes including, computerbased learning, web-based learning, virtual classrooms, and digital collaborations Technology has many positive effects on language learning, such as reading using videos (Gheytasi, Azizifar, \& Gowhary, 2015). Information technology can be accepted as a medium in carrying out the educational process, including helping the teaching and learning process (Wekke \& Hamid, 2013). Online learning can facilitate students to learn more broadly, and in variety. Through the facilities provided by this way, students can study anytime and anywhere without being limited by distance, space and time. The learning material being studied is more varied, not only in verbal form, but also more varied, such as visual, audio, and motion. In general, online learning is very different from conventional learning. Online learning influences the transformation of conventional education into digital form, both in content and in the system (Sriwihajriyah, Ruskan, \& Ibrahim, 2012). Online learning places more emphasis on students' thoroughness and foresight in receiving and processing information presented online.

The effectiveness of the learning process can be viewed from the teachers teaching activity in an attempt to achieve certain instructional goals. The effectiveness of the learning process means the level of teacher success in teaching certain groups of students by using certain 
methods to achieve certain instructional goals. Effectiveness can be viewed from the aspect of the ability of teachers to manage learning well, student activity in learning, and student learning outcomes. Learning effectiveness has two characteristics. The first characteristic is "making it easy for students to learn" something useful, such as facts, skills, values, concepts or something desired learning outcomes. Second, that skills are recognized by those who are competent to assess, such as teachers, supervisors, tutors or students themselves (Dunne, as cited in Pujiastutik, 2019).

Miarso (as cited in Rohmawati, 2015) states that the effectiveness of learning is one of the quality standards of education and is often measured by the achievement of goals, or it can also be interpreted as the accuracy in managing a situation, "doing the right things". Meanwhile, according to Supardi (as cited in Rohmawati, 2015) effective learning is a combination composed of human, material, facilities, equipment and procedures directed to change the behavior of students in a positive and better direction according to the potential and differences that students have for achieve predetermined learning objectives.

Bahasa Indonesia learning contains four aspects of language skills, namely listening, speaking, reading, and writing. Listening is a receptive skill to understand spoken language. What is meant by listening skills here does not mean simply listening to language sounds through the hearing aid, but at the same time understanding their meaning. The term listening is different from the term hearing. Although both use hearing aids, listening is different from hearing. Hearing activities do not include elements of intention, concentration, or even understanding. While in listening activities, there are elements of deliberation, carried out with full attention and concentration to obtain adequate understanding. Student is said to be skilled at listening if they have the ability to interpret the meaning of language sounds (in the form of words, sentences, and tone) conveyed by the speaker. Vega and Arifin's (2016) research result show that learning using self directed elearning can improve students listening skills. The method begins with the preparation of learning materials and accounts learning process, at the stage of the learning process, students can carry out independent learning anywhere and anytime and immediately get the results of the learning that has been done, and evaluation as the monitoring stage of instructors to learners as a follow-up to the learning activities.

Speaking is the ability to express things that are contained in daily life orally with sufficient ease and fluency so that they can be understood by the interlocutor. Speaking skills consist of three types of speaking situations, they are interactive, semi-interactive, and noninteractive. Interactive speaking situations, for example, occur in face-to-face conversations and telephone conversations. The speaking activity in this interactive situation allows a change of roles between speaking and listening. Then, there are also speaking situations that are classified as semi-interactive, for example in public speeches, campaigns, and others, whether done face-toface but in one direction. Some speaking situations can be said to be completely inactive if the conversation is carried out in one direction and not through face to face.

Reading skills are classified as active and receptive skills. Reading skills are divided into two classifications, namely a) initial reading, and b) advanced reading. The ability to read at the beginning is characterized by the ability to recognize letters, namely the ability to recognize written symbols and be able to sound them correctly. In this phase, understanding of the reading content is not very visible because the reader's orientation is more towards recognizing the symbols of language sounds. Meanwhile, in advanced reading, reading ability is marked by the ability to recognize reading. This means that readers not only recognize written symbols, can sound them fluently, but can also pick up the content / meaning of the reading they are reading. The emphasis on advanced reading lies in understanding the reading content, even at a high level it must be accompanied by an adequate reading speed. A person is said to be skilled at reading if he is able to interpret the meaning and forms of written language (in the form of words, sentences, paragraphs, written organization) that he reads. Khusniyah and Hakim's (2019) research result shows that online learning can improve students reading skills. Blogs provide a fun reading habit. However, researchers have found that blogging has no effect on test results. So, the results of this study, blogs do not have a direct impact on improving students' reading skills, but blogs can provide comfort and convenience for students in reading so that students are motivated to read.

Writing skills are skills that are actively productive. This skill is considered to occupy the most complicated and complex hierarchy among other types of language skills because writing activity is not just copying words and sentences; but rather pouring out and developing thoughts, ideas, ideas, in an orderly, logical, systematic writing structure, so that they are easily captured by the reader. A person is said to have writing skills if he or she can choose the forms of written language (in the form of words, sentences, paragraphs) and use appropriate rhetoric (writing organization) to express thoughts, feelings, ideas, facts. Syahruddin and Pongpalilu's (2014) research result show that by using ICT media through WBL in writing courses can increase student competency creative writing.

Online learning of Bahasa Indonesia is expected to be able to develop all aspects of these language skills. Online learning can be used to convey learning without being limited by space and time, as suggested by Sidek and Yunus (2012) that technology can be reached by anyone. 
Conventional learning has been largely abandoned and turned to computer-based learning or what is commonly known as online learning (Thorne, 2003; Bersin, 2004). Online learning can use various sources that are available on the internet, and teaching subject matter are relatively easy to update. Online learning helps teachers manage learning well and can increase students' independence in mastering subject matter to obtain high learning outcomes. Thus, online learning can increase the effectiveness of learning.

The various previous studies show us that the research was carried out to observe one aspect of language with using different methods so that an observation of the four aspects of language using the same media is needed to see the weaknesses and strengths that arise in Bahasa Indonesia online learning. Thus, this research was conducted to find out the effectiveness of online learning on Bahasa Indonesia during the covid-19 pandemic.

\section{METHODS}

This study used mixed-methods approach. The sample of this study were 30 students of $5^{\text {th }}$ grade student in SDN Gaddong II. Quantitative data were collected by giving tests and questionnaire. Before the instrument is used, first an analysis of the question instrument is carried out through validity and reliability tests. Validity was carried out by field trials. The validity of the test questions and questionnaires were analyzed and the results were valid instruments. The reliability test was carried out by means of a test-retest and the results showed that the instruments used were reliable. Qualitative data were collected through interviews regarding the effectiveness of online learning being conducted. The data were analyzed quantitatively and qualitatively.

\section{FINDINGS AND DISCUSSION}

Online learning continues during the covid-19 pandemic. This learning process has both good and bad impacts in improving the quality of student learning. Online learning requires students and teachers to communicate interactively by utilizing information and communication technology. The internet has been integrated as a tool to complement language learning activities (Martins, 2015). One of the technology media that is often used today is handphone. Students who interact a lot with applications on their cell phones can more easily understand the contents of the reading text. Likewise, the use of the internet in student reading blog activities (McGrath, Berggren, \& Mežek, 2016). The use of this media is used to facilitate communication in learning, especially between teachers and students. The teacher presents material in the form of text, video, images, or sound recordings that can be accessed by students through applications that can be installed on cellphones. Thus, learning will run effectively as stated by Pujiastutik (2019) that the main purpose of using this technology is to increase the efficiency and effectiveness of learning. Online learning encourages students to have cellphones that are used to access the subject and assignments. This is certainly good for students in facilitating learning activities at home during the pandemic. However, the existence of cellphones also allows students to access other things besides subject matter, including watching videos and playing games.

Online learning is done from home. As shown in Figure 1, students do other activities besides studying. Student activities at home during the learning period from home show that students use cellphones to study with a percentage of $47 \%$. Apart from being used for learning, cellphones are also used to watch videos and play games with a percentage of $23 \%$ and $17 \%$. Meanwhile, another $13 \%$ use cellphones to interact on social media. The results of the interview showed that students sometimes got bored with learning so that in between lessons students sometimes watched videos or played games for a while before continuing their study assignments. Students are also asked to respond to the preferred learning process between face-to-face learning, online learning, or blended learning. The results of student responses are presented in Figure 2. Student response data to the learning methods used show that students prefer learning in class where the teacher and students meet face to face.

Online learning is less preferred by students when compared to face-to-face learning, even blended learning is less liked by students. The results of the interview showed that students preferred learning in class because they used to interact directly with teachers and friends.

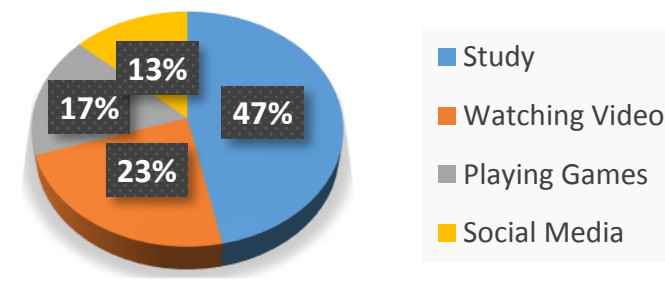

Figure 1 Student activity at home.

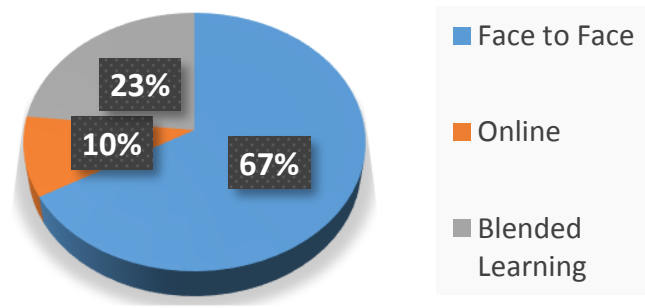

Figure 2 Student responses on learning method. 
This does not happen if learning is done online, student interactions with other students are very limited and even rare because interactions are only done with the teacher. Blended learning is preferred over online learning because in blended learning students still interact directly. Students can ask directly about subject that is considered difficult.

Online learning is carried out in 3 ways, using the Zoom application, WhatsApp and Instagram as shown in Figure 3. Student responses show that students like learning done using the Zoom application compared to learning via WhatsApp or Instagram. Through the Zoom application, teachers and students can have discussions related to the material being studied. Yazdi (2012) suggests that through the discussion method, teachers and students can interact directly, making it easier for students to learn online. From the results of the interview, it was obtained the students' opinion that learning using the Zoom application was more fun because they could meet virtually with other friends. This encourages them to be more enthusiastic about receiving the subject matter. Learning can be more attractive for student because they can communicate each other in zoom.

Tests are given to students before and after the implementation of online learning on Bahasa Indonesia. The data were analyzed to find the gain score between pretest and posttest. The results in Table 1 show that listening skills are in the high category with 0.913 gain score between pretest and posttest while reading skills are in the middle category with a 0.647 gain score. Meanwhile, two other skills, speaking and writing skills, are in the poor category with -0.044 and -0.026 gain score between pretest and posttest. From these results it can be argued that online learning is effective on listening and reading skills but ineffective on speaking and writing skills.

Learning has been carried out on all four language skills. Listening includes identifying, interpreting language sounds and then assessing the results of interpretation of meaning and responding to the messages implied in the discourse. Learning activities carried out through zoom provide the opportunity for teachers and students to meet face to face virtually. The teacher presents material that can be heard directly by students. This learning process helps students improve their listening skills. Students are able to understand the material explained and able to identify the topic or main idea of the teacher's explanation.

Speaking skills learning includes the ability of students to convey intentions (ideas, thoughts, contents) using oral language so that the meaning can be understood by the teacher and his friends. The results obtained did not show an increase in students' speaking skills. Submission of ideas or opinions by students does not contain ideas or does not show the extent of information students have regarding the material being studied.

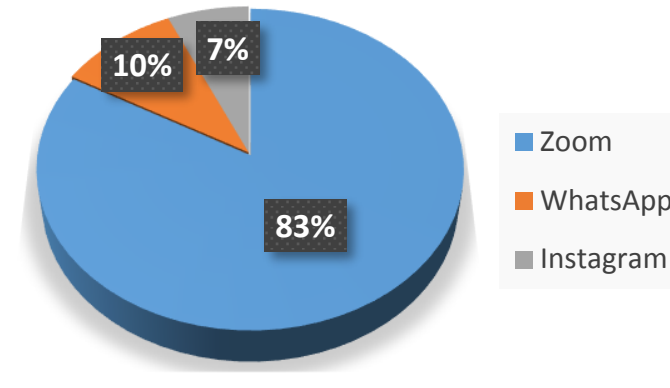

Figure 3 Student responses to the application used.

Table 1. Categorization of language skill

\begin{tabular}{|c|c|c|}
\hline Language Skill & $\begin{array}{c}\text { N-Gain } \\
\text { Score }\end{array}$ & Category \\
\hline Listening & 0,913 & High \\
\hline Speaking & -0.044 & Decrease \\
\hline Reading & 0,647 & Average \\
\hline Writing & $-0,026$ & Decrease \\
\hline
\end{tabular}

This is possible because the online learning process limits students' opportunities to ask the teacher about things that are not understood. This limitation makes students less informed about the topics discussed. Even though a lot of information is available and easily accessible via the internet, students still need guidance from the teacher to understand the information.

Online learning that is carried out presents a lot of assignments in text form so that students' reading skills can be trained properly. Students can recognize words and sentences well and understand the meaning contained in these sentences. However, different results were found in the learning of writing skills. In students' writing skills, they did not show any improvement as in reading skills. Students are less able to use sentence structure properly. The ideas that students want to convey cannot be put into writing. Djuharie and Suherli (2005) said writing is a skill that can be nurtured and trained. Writing activities can be carried out by everyone by being nurtured and trained. However, to be implemented online, it is difficult to train students to be skilled in writing.

Interviews were conducted to obtain an overview regarding Bahasa Indonesia learning which was conducted online. In general, from the aspect of student convenience in learning, information is obtained that online learning makes learning easier for students. Students can study anywhere and anytime via the internet. Through this access students can download subject matter and do assignments given. however, although learning can be done easily, the students' language skills do not improve equally. The skills that tend to improve are listening and reading skills. Conversely speaking and 
writing skills have decreased. So, it can be said that online learning on Bahasa Indonesia is effective for improving listening and reading skills but ineffective for improving speaking and writing skills.

Respondents were asked for their responses regarding the strengths and weaknesses they found during the online learning process. Respondents argued that through online learning, students could seek information from various sources to complete assignments given by educators, such as the internet and applications that were devoted to learning. This can be categorized as the advantage of online learning because students can explore their knowledge more deeply. If usually students learn more passively in class, then with this online learning students can be more active because they can find their own knowledge so that the knowledge gained can be more meaningful. Online learning can be done at any time according to the agreement between the educator and the students. This means that online learning can be done in the morning, afternoon, evening, or even at night as long as the educator has made an agreement with the students long before the learning process begins, because making an agreement that is too sudden will also make it difficult for teachers and students. Online learning can be done anywhere. In this case, this means that during a pandemic, not allowing everyone to travel will not hinder this online learning process. Because this online learning does not require face-to-face activities between educators and students.

The other information got from respondent that weaknesses encountered during the online learning process, including the teacher's role as a facilitator, were not fulfilled. This is due to the limited interaction between educators and students, if during learning in the classroom educators can observe students directly, then during online learning it is rather difficult to observe all students because it is limited by long distances. For example, students find it difficult to contact educators to ask for material that students do not understand. Online learning requires a fairly large internet quota. This is because the use of the internet is one of the main points in online learning. To access various websites and applications used in online learning requires more internet quota compared to classroom learning. If learning in the classroom uses the internet only as a support in learning, then the internet network in online learning is something that must be used. Online learning cannot be done without the use of the internet, because the media used in online learning is a medium that can be used only if it is connected by internet access. Another deficiency stated by the respondents was the signal or internet network constraints during the learning process. This often happens during the online learning process. Internet connections for educators or students can experience interference due to poor signals or networks. Therefore, the implementation of online learning is still very difficult to implement as much as possible due to signal constraints that still occur during this online learning.

Online learning as a method is able to provide great benefits for teachers and students, therefore teachers need to understand online learning in order to make optimal use of it for the learning interests of their students. Online learning makes the learning process easy and fun, so that it creates students' interest in learning in a different way than usual. Students can study anywhere at any time. Online learning provides independent learning through assignments given online. Students access the material and work on the assignment given then collect the assignment online. However, online learning has advantages and disadvantages. Therefore, teacher need to find any strategies that can be conducted effectively on online learning.

\section{CONCLUSION}

The conclusion that can be drawn from this research is that online learning on Bahasa Indonesia is effective on listening and reading skills but ineffective on speaking and writing skills. The obstacles faced in the online learning process are the availability of internet networks, the smoothness of the learning process depends on the strength and weakness of the signal in the area where students live. Another problem is the availability of internet quota. Students learn various subject matter taught online, so students need a lot of internet quota to be able to access learning from home.

\section{REFERENCES}

Bersin, J., (2004). The blended learning book: Best practices, proven methodologies, and lessons learned. San Francisco, CA: Pfeiffer.

Djuharie, O. S., \& Suherli. (2005). Panduan membuat karya tulis. Bandung: Yrama Widya.

Gheytasi, M., Azizifar, A., \& Gowhary, H. (2015). The effect of smartphone on the reading comprehension proficiency of Iranian EFL learners. Procedia-Social and Behavioral Sciences, 199, 225-230.

Keengwe, J., \& Georgina, D. (2012). The digital course training workshop for online learning and teaching. Education and Information Technologies, 17(4), 365-379.

Khusniyah, N. L. \& Hakim, L. (2019) Efektifitas pembelajaran berbasis daring: Sebuah bukti pada pembelajaran bahasa Inggris. Jurnal Tatsqif, 17(1), 19-33.

Martins, M. de L. (2015). How to effectively integrate technology in the foreign language classroom for learning and collaboration. Procedia-Social and Behavioral Sciences, 174, 77-84. 
McGrath, L., Berggren, J., \& Mežek, Š. (2016). Reading EAP: Investigating high proficiency L2 university students' strategy use through reading blogs. Journal of English for Academic Purposes, 22, 152-164.

Pujiastutik, H. (2019). Efektivitas penggunaan media pembelajaran e-learning berbasis web pada mata kuliah Belajar Pembelajaran I terhadap hasil belajar mahasiswa. Jurnal Teladan: Jurnal Ilmu Pendidikan dan Pembelajaran, 4(1), 25-36.

Rohmawati, A. (2015). Efektivitas Pembelajaran. Jurnal Pendidikan Usia Dini, 9(1), 15-32.

Sidek, E. A. R., \& Yunus, M. Md. (2012). Students' experiences on using blog as learning journals. Procedia-Social and Behavioral Sciences, 67, 135143.

Sriwihajriyah, N., Ruskan, E. L., Ibrahim, A. (2012). Sistem pembelajaran dengan E-learning untuk persiapan ujian nasional pada SMA Pusri Palembang. Jurnal Sistem Informasi (JSI), 4(1), 450467.
Syahruddin \& Pongpalilu, F. (2014). Inovasi pembelajaran menulis kreatif melalui web-based learning. Jurnal Pendidikan dan Pembelajaran, 2l(2), 146-154

Thorne, K., (2003). Blended learning: How to integrate online \& traditional learning. London \& Sterling, VA: Kogan Page Limited.

Vega, N. D. \& Arifin. (2016). Penerapan Self Directed ELearning Pada Keterampilan Menyimak. Jurnal Masyarakat Telematika dan Informasi, 7(2), 107118.

Wekke, I. S., \& Hamid, S. (2013). Technology on language teaching and learning: A research on Indonesian pesantren. Procedia-Social and Behavioral Sciences, 83, 585-589.

Yazdi, M. (2012). E-learning sebagai media pembelajaran interaktif berbasis teknologi informasi. Jurnal Ilmiah Foristek, 2(1), 143-152. 